\title{
Devaluation of persons by biotechnology-facilitated practices at the beginning and at the end of life
}

Bjørn Hofmann, Department for the Health Sciences, Norwegian University of Science and Technology, Gjøvik, and Centre for Medical Ethics, University of Oslo.

Abstract

Although Phil Reed certainly advances the expressivist debate, it is not clear that the objections to the expressivist argument are so different at the end compared to the beginning of life or that this adds to and substantiates the arguments against physician assisted suicide and euthanasia.

Moreover, it is not obvious that the traditional objections to the expressivist argument, e.g., that there is no message, no sender, and no receiver, have such a strong bite - neither at the beginning nor at the end of life. Biotechnologies are normative in many ways. We implement them normatively to obtain certain values. At the same time, they facilitate certain actions and establish practices which form our norms, either intended or unintended. In either case, we need to pay attention to them, as they form us as individuals and as societies. 


\section{Devaluation of persons by biotechnology-facilitated practices at the beginning and at the end of life}

In this original and interesting article, ${ }^{1}$ Phil Reed argues that the objections launched against expressivism at the beginning of life do not apply to expressivism at the end of life. Moreover, he claims that the expressivist argument adds to and substantiates the arguments against physician assisted suicide and euthanasia (PAS/E). In this commentary, I will:

1. Briefly examine whether the comparison between expressivism at the beginning and at the end holds.

2. Scrutinize whether there is a trickle down-effect of expressivism at the end of life on other arguments against PAS/E.

3. Examine one version of the expressivist argument that is not discussed by Reed both at the beginning and at the end of life.

\section{Expressivism at the beginning and end of life}

Table 1 shows the three arguments against expressivism that Reed discusses, and the problems with these arguments at the beginning of life, as well as why they are not a problem at the end of life according to Reed.

Table 1 Reconstruction of Reeds analysis of three arguments against expressivism, what are the problems with these arguments at the beginning of life and why Reed thinks that they are not a problem at the end of life

\begin{tabular}{|c|c|c|}
\hline $\begin{array}{l}\text { Counterarguments to } \\
\text { expressivism }\end{array}$ & $\begin{array}{l}\text { Problems with expressivism at the } \\
\text { beginning of life }\end{array}$ & $\begin{array}{l}\text { Why the problems with } \\
\text { expressivism are not that severe } \\
\text { at the end of life }\end{array}$ \\
\hline $\begin{array}{l}\text { 1. Negative belief or } \\
\text { attitude is actually } \\
\text { not expressed }\end{array}$ & $\begin{array}{l}\text { No explicit assessment that a life is } \\
\text { not worth living. Rather, the } \\
\text { person is not ready emotionally or } \\
\text { financially to handle a child with } \\
\text { disability. }\end{array}$ & $\begin{array}{l}\text { More explicit assessment of } \\
\text { whether a life is worth living or } \\
\text { not. } \\
\text { The quality of life is so poor that } \\
\text { one is better off dead. }\end{array}$ \\
\hline Explanation & $\begin{array}{l}\text { Greater range of possible meanings } \\
\text { (preparation, reproductive choice, } \\
\text { not only abortion) }\end{array}$ & $\begin{array}{l}\text { More narrow and targeted } \\
\text { meaning: life is not worth living. }\end{array}$ \\
\hline $\begin{array}{l}\text { 2. Rights to autonomy } \\
\text { trump negative } \\
\text { attitudes potentially } \\
\text { expressed }\end{array}$ & $\begin{array}{l}\text { Disrespect to persons with specific } \\
\text { conditions weights less than } \\
\text { reproductive autonomy. }\end{array}$ & $\begin{array}{l}{[T] \text { he right to die does not require }} \\
\text { medical assistance in the way that } \\
\text { the right to reproductive } \\
\text { autonomy does," hence it is not } \\
\text { clear that autonomy will be } \\
\text { violated or needs to be trumped }\end{array}$ \\
\hline Explanation & $\begin{array}{l}\text { Depending on third party (health } \\
\text { professionals): Testing, abortion }\end{array}$ & $\begin{array}{l}\text { Not depending (as much) on third } \\
\text { parties (health professionals) }\end{array}$ \\
\hline $\begin{array}{l}\text { 3. The purposes of the } \\
\text { practice is not to } \\
\text { express negative } \\
\text { attitudes towards } \\
\text { people }\end{array}$ & $\begin{array}{l}\text { The purpose of prenatal screening } \\
\text { and reproductive technologies is to } \\
\text { avoid the existence of persons with } \\
\text { disabilities, not to say anything } \\
\text { about the value of their lives. }\end{array}$ & $\begin{array}{l}\text { Act on (and target) already existing } \\
\text { people. } \\
\text { End-of-life decisions are not } \\
\text { preventive, they are life-ending. }\end{array}$ \\
\hline
\end{tabular}




\begin{tabular}{|c|l|l|}
\hline & $\begin{array}{l}\text { Prenatal testing does not target } \\
\text { anyone who already exists. It } \\
\text { targets potential persons. }\end{array}$ & $\begin{array}{l}\text { Laws identify persons with } \\
\text { disability to be a class of people } \\
\text { who have acceptable reasons for } \\
\text { wanting to die. }\end{array}$ \\
\hline Explanation & $\begin{array}{l}\text { Preventing the existence of } \\
\text { persons with specific disabilities }\end{array}$ & $\begin{array}{l}\text { Ending the life of persons with } \\
\text { specific disabilities }\end{array}$ \\
\hline
\end{tabular}

Reed assumes that the attitudes at the beginning of life are less explicitly expressed than at the end of life as the reproductive choice may have many motivations beyond the belief that a life with a specific disability is not worth living. At the end of life, PAS/E represents a more explicit assessment: life is not worth living. However, even at the end of life, there may be many reasons for the decision. Moreover, as Reed acknowledges, the expression is not dependent on the intentions of the actors, but on the normative function of legislation and actions.

According to the second argument, there is less chance that the autonomy will be undermined at the end of life than at the beginning of life, as one is less dependent on third-party involvement at the end of life. You can choose suicide. However, Reid seems to be wrong in claiming that "the right to reproductive control is exercised only with the cooperation of the medical profession." Following his line of argument, a woman can choose (not) to become pregnant or to take abortion. The latter does not necessarily require help from medical professionals.

The third argument assumes that the actions at the beginning of life are less targeted than at the end of life. According to Reed, preventing the existence of a person is different from ending the life of a person. "PAS laws target disabled persons themselves compared to prenatal testing or selective abortion, which targets only potential persons." However, the relevance of this difference is unclear. What is common both at the beginning and at the end of life is the aim to avoid the life of a person with certain characteristics. Legislative criteria identify the group of persons (e.g., with Downs syndrome or specific disabilities) while the actions (e.g., abortion or PAS/E) indicate their values. Again, the signal or expression is independent of intention.

Hence, it is not clear that "expressivism at the end of life is a much greater concern than at the beginning." It is still not clear that there is a specific message sent to persons with disability at PAS/E.

\section{No trickle-down effect}

Accordingly, it may be difficult to claim that there is a trickle-down effect, i.e., that the expressivist arguments make other arguments against PAS/E more serious. Pace Reed, "if negative attitudes about disabled lives are entrenched or exacerbated, this could make the choice of a disabled person to die even less autonomous than it would otherwise be." If this is true, then such decisions would not be autonomous, and strictly speaking, PAS/E in such cases would not be legal.

This relates to my next point, that there are expressivist arguments that are more forceful than the one discussed by Reed.

\section{Wrong receiver argument}

According to Reed, "it is not the case that negative attitudes about disability expressed by prenatal testing will trickle down to embryos or fetuses and cause them to think of themselves as inferior or less valuable." Certainly, nobody believes that negative attitudes will harm aborted fetuses. The negative attitudes harm existing persons with the condition searched for. The expressivist argument does neither presume intentions of the sender nor there being a specific receiver in the individual instance. Rather, a stronger version of the expressivist argument claims 
that the sender is the system (in terms of regulations and executing institutions) searching for specific conditions or disabilities; the message is given by the value implicit in the action (abortion or PAS/E); and the receivers are the persons living with this condition. ${ }^{2}$ For example, what makes us search for and offer abortion for fetuses with trisomy 21 is not our experiences with and devaluation of excessive chromosomes, but our experience with and assessment of existing persons with Down's syndrome.

Accordingly, the message ("you are inferior" or "your life is so poor that it is worth avoiding") is not intentionally sent from individuals making procreative decisions, but from the system implicitly. And it is clearly not received by aborted fetuses, but to living persons with Down's syndrome and to society at large. The same goes for the end of life. Hence, the important thing is how specific the eligibility criteria for avoiding/ending life are, not whether it is at the beginning or at the end of life.

\section{Conclusion}

Although Reed certainly advances the expressivist debate, more work is needed to ascertain the difference of the argument at the beginning and the end of life and to assert its forcefulness in the PAS/E debate. Moreover, it is not clear that the traditional objections to the expressivist argument, e.g., that there is no message, no sender, and no receiver, have such a strong bite neither at the beginning nor at the end of life.

Biotechnologies are normative in many ways. We implement them normatively to obtain certain values. At the same time, they facilitate certain actions and establish practices which form our norms, i.e., they are norm-formative. Such norms may be intended or unintended. In either case, we need to pay attention to them, as they form us as individuals and as societies.

\section{References}

1. Reed P. OnlyExpressivism at the Beginning and End of Life. Journal of Medical Ethics 2020(medethics-2019-105875.R1)

2. Hofmann B. 'You are inferior!' Revisiting the expressivist argument. Bioethics 2017;31(7):505-14. doi: 10.1111/bioe.12365 [published Online First: 2017/06/15] 